University of Nebraska - Lincoln

DigitalCommons@University of Nebraska - Lincoln

2008

\title{
Linking Ecosystem Processes with Wetland Management Goals: Charting a Course for a Sustainable Future
}

Ned H. Euliss Jr.

U.S. Geological Survey, ceuliss@usgs.gov

Loren M. Smith

Oklahoma State University - Main Campus

Douglas A. Wilcox

SUNY-Brockport, dwilcox@brockport.edu

Bryant A. Browne

University of Wisconsin - Stevens Point

Follow this and additional works at: https://digitalcommons.unl.edu/usgsnpwrc

Euliss, Ned H. Jr.; Smith, Loren M.; Wilcox, Douglas A.; and Browne, Bryant A., "Linking Ecosystem Processes with Wetland Management Goals: Charting a Course for a Sustainable Future" (2008). USGS Northern Prairie Wildlife Research Center. 272.

https://digitalcommons.unl.edu/usgsnpwrc/272

This Article is brought to you for free and open access by the US Geological Survey at DigitalCommons@University of Nebraska - Lincoln. It has been accepted for inclusion in USGS Northern Prairie Wildlife Research Center by an authorized administrator of DigitalCommons@University of Nebraska - Lincoln. 


\title{
LINKING ECOSYSTEM PROCESSES WITH WETLAND MANAGEMENT GOALS: CHARTING A COURSE FOR A SUSTAINABLE FUTURE
}

\author{
Ned H. Euliss, Jr. ${ }^{1}$, Loren M. Smith ${ }^{2}$, Douglas A. Wilcox ${ }^{3,4}$, and Bryant A. Browne ${ }^{5}$ \\ ${ }^{1}$ U.S. Geological Survey \\ Northern Prairie Wildlife Research Center \\ $871137^{\text {th }}$ Street $S E$ \\ Jamestown, North Dakota, USA 58401 \\ E-mail: ceuliss@usgs.gov \\ ${ }^{2}$ Department of Zoology \\ Oklahoma State University \\ Stillwater, Oklahoma, USA 74078 \\ ${ }^{3}$ U.S. Geological Survey \\ Great Lakes Science Center \\ 1451 Green Road \\ Ann Arbor, Michigan, USA 48105 \\ ${ }^{4}$ Present Address: \\ Department of Environmental Science and Biology \\ 350 New Campus Drive \\ $S U N Y$-Brockport \\ Brockport, New York, USA 14420 \\ ${ }^{5}$ College of Natural Resources \\ University of Wisconsin-Stevens Point \\ Stevens Point, Wisconsin, USA 54481
}

\begin{abstract}
Wetland management in the United States has never been as challenging as in today's highly modified landscape. Initially, wetland science and management emerged as professions in response to widespread conversion of wetlands to other uses and concerns over negative impacts on wildlife populations, especially migratory birds. Consequently, wetland management was focused on wildlife, and the initial management technique was simply to protect wetlands. However, extensive conversion of lands for agricultural and urban expansion over the past 60 years has modified ecosystem processes at the landscape scale sufficiently to compromise wetland management activities on adjacent lands dedicated to conservation. Moreover, society now expects a broad suite of ecosystem services to be delivered. As a result, many previously used wetland management techniques are no longer appropriate because they do not take into account influences of adjacent land uses or other ecosystem services, such as ground-water recharge. Other early management approaches may have been ineffective because they were based on an incomplete understanding of wetland processes or social influences. Meanwhile, wetland losses continued, as well as loss of services provided by the remaining managed wetlands. Regulation starting in the 1970s and subsequent research attention on wetland functioning has led to new knowledge and a broader understanding of wetland processes and recognition of the full suite of services (e.g., water storage, water quality improvement, aquifer maintenance, climate mitigation). To be effective in today's highly modified landscape, knowledge of social choices, political influences, and dynamic wetland processes is required to meet wetland management objectives for a range of ecosystem services. We argue that adopting a process-based perspective is critical to develop strategies to optimize a suite of wetland services, including providing traditional wildlife habitat.
\end{abstract}

Key Words: wetland ecology, wetland processes, wetland science, wildlife management 


\section{INTRODUCTION}

Recognition of the role that complex interactions and processes play in maintaining ecosystems, coupled with increasing demands of humans for ecological goods and services over the past several decades, has prompted much interest in ecosystem management (e.g., GAO 1994, Baettie 1996, Reichman and Pulliam 1996). Not surprisingly, sustainability of ecosystems has become an explicitly stated goal of many natural resource agencies and, in some cases, has been legislatively mandated to ensure provision of resources for future generations (Christensen et al. 1996). However, examples of sustainable ecosystem management are uncommon because management goals often focus on specific deliverables rather than processes that sustain ecosystems. To provide guidance, the Ecological Society of America formed a committee to provide a scientific basis for ecosystem management (Christensen et al. 1996). The committee defined goals that focused on intergenerational sustainability, fundamental precepts for ecosystem management, and a general strategy to transition from concept to practice. Hence, the concept of ecosystem management is not new, but there are few examples where it has been applied in natural resource management. Herein, we provide specific guidance to help wetland managers link natural resource management goals with critical ecosystem processes responsible for wetland function and sustainability.

To do so with a minimum of semantic confusion, it is important to operate with well-defined terms. Here, we define ecological processes (e.g., nutrient cycling, decomposition) as internal determinants of wetland function and values. Next, ecosystem processes include ecological processes but also external drivers (e.g., watershed variables, climate) of wetland function that operate on a much larger spatial scale. Herein, we submit that external ecosystem processes are the primary drivers of wetland site change through their influence on ecological processes. While the most basic feature of wetlands is water, hydrologic function, along with the physical and geochemical characteristics of soils and in concert with climate, defines the unique abiotic features of specific wetland ecosystems and the biota they support (Harris and Marshall 1963, National Research Council 1995, Mistch and Gosselink 2007).

Prior to the conservation movement and the dedication of lands for fish and wildlife conservation, private lands were indiscriminantly modified from their natural state into agricultural cropland and other land uses to support a growing human population (National Research Council 1995, Mitsch and Gosselink 2007). In the early 1900s, concerns over declines in fish and wildlife populations, especially for game species, stimulated the conservation movement. These early management efforts to conserve fish and wildlife were often aimed at simply protecting conservation lands from development. At the time, the U.S. landscape was not highly modified, and basic ecosystem processes driving wildlife populations were more or less intact. Wetland functions and ecosystem processes were not generally understood or considered important, and ecosystem processes influencing wetlands were not generally included in formal curricula or postgraduate training for most wetland managers.

Over the last 60 years, habitat loss and declines in wildlife populations provided much of the impetus for intensive wetland management and protection. Much attention was frequently focused on outcomes for wetland birds and their habitats. The National Wildlife Refuge system was formed in 1942, and almost all initial refuge acquisitions were wetland systems. Many were purchased with migratory bird stamp funds generated from waterfowl hunters (Salyer and Gillet 1964). Management actions were numerous and diverse, including such activities as impounding perennial and intermittent streams to expand wetland area, maintaining static water levels in otherwise seasonally inundated wetlands, creating islands in natural wetlands for protection of breeding waterfowl from predators, using nontraditional water sources where water is scarce (e.g., agricultural return flows, ground water), and manipulating native and non-native plant communities to favor game species. However, habitat dynamics or critical ecosystem processes responsible for creating and maintaining habitats received little consideration in these prescriptions (Smith 1990). Importantly, the surrounding landscape or watershed was often ignored as an influential factor and considered to have little effect on wetland processes needed to maintain wildlife populations.

As the human population has increased over the past century, the demand for resources provided by ecosystems increased over fivefold (e.g., Karlin 1995). As a result, entire landscapes have been modified for human use and what remains is highly altered. Modern land-use changes have left us with altered ecosystem processes, and we are beginning to document the consequences of biological thresholds being reached (Skorupa and Ohlendorf 1991, Nelson and Reiten 2006). For example, more than $90 \%$ of U.S. streams, ground water, stream and estuarine sediments, and freshwater fish have at least one contaminant at detectable levels (Heinz Report 
2002). The primary sources of contaminants are excess sediments, nutrients, and toxicants, indicating that land use that alters fundamental ecological processes (e.g., hydrodynamics, erosion, nutrient cycling, and eutrophication) is a leading contributor to degradation (U.S. Environmental Protection Agency 2000). Thus, land-use factors including sedimentation of natural and managed wetlands, altered surface and subsurface hydrology, and excessive accumulations of dissolved constituents (e.g., salts, heavy metals, agrichemicals) in aquatic habitats now commonly confound efforts to manage habitats for conservation (e.g., Ohlendorf et al. 1986, Gleason et al. 2003, Smith et al. 2008).

All watershed and wetland management activities influence the function of specific ecosystem processes responsible for temporal habitat dynamics. Clearly, conservation goals of specific wetland areas can be compromised by adjacent and upstream land uses (Luo et al. 1997, Merbach et al. 2002, Gleason et al. 2003). Moreover, infrastructures and methods typically used to manage wetlands for wildlife may not account for the natural and dynamic hydrologic processes or perturbations at larger scales; hence, many are poor "fits". Understanding how various conservation activities influence specific ecosystem processes and the concomitant ecological response of biota is requisite to implement effective wetland management.

Although interest in protecting wetlands in the U.S. began with concern over migratory birds, that interest has broadened in time to include a suite of ecosystem goods and services that wetlands provide to society. Wetland conversion and degradation and their importance to migratory birds led to the enactment in 1958 of the small wetlands acquisition program (Public Law 87-383), supported largely with funds from hunters. However, a growing awareness of wetland functions, such as water quality improvement, water storage and detention, and a broader view of biodiversity by society led to the 1972 Federal Water Pollution Control Act (Public Law 92-500) and amendments to Section 404 of the Federal Water Pollution Control Act (Clean Water Act; Public Law 95-217) in 1977. We are only beginning to document the full suite of services that natural wetlands provide to society, and future research will likely identify additional important societal benefits derived from wetlands (http://www.nrcs.usda.gov/technical/NRI/ceap/wetlands, National Research Council 1995 and 2002). Recent studies of the role that wetlands play in sequestering carbon (Bridgham et al. 2006, Euliss et al. 2006) and reducing trace gas emissions (Merbach et al. 2002) are examples of previously unknown and important societal benefits of maintaining fully functional wetlands in the landscape.

The interest in wetlands from the perspective of basic human services (e.g., water quality improvement) is not exclusive of traditional wildlife management goals. Indeed, managing for the full suite of wetland services requires that wetlands go through wet/dry cycles characteristic of a specific geomorphic setting (Junk et al. 1989, Euliss et al. 2004). Wildlife populations naturally fluctuate through these cycles. Hence, an understanding of how a specific site formed geologically and hydrologically and of how physical and chemical processes function there naturally is critical for effective management of all services, including wildlife (Keough et al. 1999, Smith et al. 2008).

A new perspective needs to be developed, not to return wetlands or other habitats to pre-settlement conditions (an unrealistic outcome given requirements to support human populations and previous non-reversible changes), but to achieve long-term sustainability of critical habitats within the constraints of altered landscapes by restoring or simulating natural ecosystem processes. Wetland conservation areas must be managed from a perspective that takes into consideration the confounding influences of the surrounding watershed on wetland function (Junk et al. 1989, Merbach et al. 2002). Conservation strategies and techniques need to be developed and implemented to mitigate negative outside influences while managing ecosystem processes.

The consideration of all wetland services will present new opportunities and challenges for traditional wetland/wildlife management strategies. New wetland projects will require the application of knowledge of the many scientific disciplines that contribute to the understanding of ecosystem processes on wetland structure and function. This will ensure that emphasis placed on specific services (e.g., water quality, carbon storage) does not negatively impact the full suite of services provided by wetlands. Hence, strategies need to be developed that identify the optimal performance of a suite of ecological services provided by wetlands to ensure sustained function over the longest possible period of time.

\section{IMPROVEMENT OF CURRENT MANAGEMENT STRATEGIES}

Wetland management is a relatively new field, and many managers were traditionally trained as wildlife biologists, where the emphasis has been on wildlife populations rather than ecosystem processes. For 
example, historically, a primary interest was developing knowledge regarding how a given management action influenced populations or habitat structure of wetland birds. Much research has been conducted on developing strategies to manipulate vegetation communities to provide resources for waterfowl (see review in Mitsch and Gosselink 2007). Examples include moist-soil management, green tree reservoir management, and numerous plantcontrol strategies that involve disking, deep flooding, and chemical treatments. However, wetland management strategies, especially for wildlife, were generally implemented without consideration of most landscape-scale ecosystem processes or the ecological processes specific to the site or watersheds where these management techniques were applied (Smith 1990).

In today's environment, many wetlands are impacted by activities resulting from physical, offsite activities and societal decisions that have either constrained the ability to implement or modified responses of habitats to many commonly used strategies. For example, existing moist-soil management techniques often stimulate germination of nonnative species, many of which can be invasive in later successional stages (Fredrickson and Taylor 1982). Natural flood pulse processes have been virtually eliminated due to damming of rivers, causing loss of habitat and reducing inputs of sediments to bays and estuaries (Middleton 2002). In the northern U.S., deep flooding to control cattail populations has been compromised by limited water availability and accelerated sedimentation rates from soildisturbing activities in uplands (Swanson 1992, Swanson et al. 2003). As shown in these few examples, wetland managers are currently faced with a much more complex task to provide critical habitat. The skill set required to be effective is much broader than in the past; a deeper understanding of hydrologic, climatic, and other abiotic drivers of ecosystem function is required to make strategic management decisions within the context of landuse change (Smith et al. 2008, Wilcox 2008).

Managers also are under increasing pressure to provide habitats for a greater diversity of species and simultaneously provide recreational opportunities for a more demanding human population. Collectively, these and other changes have resulted in the profession of wetland management becoming a multidisciplinary occupation that involves not only understanding complex and changing ecological interactions, but also the integration of social, political, and economic factors into management plans. Ensuring the sustainability of remaining wetlands will require cooperation between research and management to develop new strategies that can be implemented at various spatial scales to overcome these challenges. Today, managers also need the social skills to deal effectively with the human dimension and coordinate management activities in different social and political settings (Smith et al 2008).

Clearly, the wetland conservation perspective needs to be modified and refined as needed to "fit" better within 1) the context of ecosystem processes and 2) social and political realities. The most effective means to identify optimal management scenarios may be within the context of "Ecological Fit," which has been defined as how well a specific land-use or management activity "fits" within the specific ecosystem processes that characterize specific locations, whether natural or influenced by man (Euliss and Laubhan 2005).

To place the functioning of wetlands into an effective framework for management in today's highly modified landscape, we suggest that geomorphology be the initial focus because it constrains the expression of hydrology and the full suite of abiotic features for unique ecosystems across all temporal scales (Brinson 1993, Bedford et al. 1999). Such a perspective will make it easier to understand how specific ecosystem processes are affected and how they relate to conservation outcomes. We do not suggest that wetland scientists and managers have not applied the process we are advocating. Indeed, in an accompanying manuscript (Smith et al. 2008), we present case studies where this perspective has been used. Our motivation is simply to see this viewpoint more broadly and immediately applied. This perspective was initially proposed by Brinson (1993) as a method to recognize how geomorphic setting influences wetland function and to apply that knowledge in assessment relevant to regulatory procedures; it was termed the Hydrogeomorphic Method (HGM).

\section{WETLAND MANAGEMENT BASED ON ECOSYSTEM PROCESSES: A DIFFERENCE IN PERSPECTIVE}

While the traditional wetland management focus on specific populations of wildlife has advanced our understanding of species biology, it has not contributed to our understanding of how habitats are maintained by critical ecosystem processes that have sustained them over time. Most managed wetlands are manipulated to maintain a static temporal relationship between wildlife productivity and specific habitat conditions. Yet, the ecosystem processes that sustainably yield specific habitat conditions and 
wildlife productivity have an important temporal component to consider (Junk et al. 1989, Euliss et al. 2004). Furthermore, management has mostly been directed towards wetlands and wetland conservation lands as isolated habitats rather than as nested within larger, and often highly modified, landscapes (Mensik and Paveglio 2004).

There must be ecological fit between management prescriptions and the position of wetlands in space and time in order to achieve sustainability. Whether or not a particular management prescription can be applied successfully at a specific site depends significantly on the spatial and temporal context in which it was developed. For example, in the Prairie Pothole Region (PPR) of North America, sciencebased information for a specific wetland type cannot necessarily be applied to management of a different wetland type. Likewise, information derived during a dry phase cannot be applied to the same wetland type during a wet period (Euliss et al. 2004).

The hemi-marsh concept is an important example of a management goal frequently at odds with ecological fit. Although many wetland managers strive to produce hemi-marshes, the hemi-marsh, a 50:50 mixture of open water and vegetation, is one of the most poorly understood and misapplied goals of wetland managers. Hemi-marsh conditions are important to migratory birds in prairie wetlands (Weller and Spatcher 1965, Weller and Fredrickson 1974). The body of scientific knowledge about hemimarshes came from research conducted in an area formed by the Mankato Lobe during the Wisconsin period of glaciation, an area with the highest precipitation in the PPR and with severe alterations (i.e., the study wetlands used to generate the hemimarsh concept had been highly modified from their natural state). Managers often replicate the physical appearance of hemi-marshes by intense management (i.e., mowing, herbicides, and water-level manipulations). However, without recreating the hydrologic processes that form and maintain hemi-marshes naturally through wet/dry cycles, they may lack the desired biotic productivity (Euliss et al. 2004). The key to creating productive hemi-marshes is to alter the trophic composition through natural succession, a process that temporally recycles nutrients from one biotic community to another by periodically alternating wet and dry conditions (Kadlec 1962). Hence, the process is to facilitate repeated drying and reflooding at multi-annual time scales to achieve optimal production of diverse services over the long term (e.g., Harris and Marshall 1963, Junk et al. 1989, Euliss et al. 2004) rather than vegetation control to create a hemi-marsh in appearance only.
The alteration of natural hydrologic cycles by traditional management approaches can have cascading negative effects on ecosystem processes (Gosselink and Turner 1978, Mitsch and Gosselink 2007, Mälson et al. 2008 and references cited within). In most inland managed wetlands, watercontrol structures were designed to hold water at specific elevations higher and with less fluctuation in water depth than the historical norm. This stable and extended hydroperiod can suppress the hydrologic regime necessary for processes inherent to the geomorphic setting in favor of relatively homogenous, impoundment-like biogeochemical cycling of a modified wetland type (Gosselink and Turner 1978, Jaworski and Raphael 1978, Mitsch and Gosselink 2007). The effects on hydrologic heterogeneity are enormous. The more sustained (temporal) and broader (spatial) inundation can suppress the expression of patchy moisture conditions (e.g., ground-water discharge and recharge features) and their temporal fluctuations. For example, local ground-water discharge zones may be reversed by the backpressure of the higher water level, while former ground-water recharge zones become fed by upland runoff as well as direct precipitation (Winter 2003). Hence, biotic associations and trophic patterns across subtle and gross subsurface and surface moisture gradients within the wetland may diminish or disappear (Euliss et al. 2004).

Further, as in any lake or impoundment, the process of holding water behind the control structure changes the entire ecology of the wetlands and may force the system toward eutrophy (Jaworski and Raphael 1978, Brix 1993). Due to the larger storage volume and longer hydraulic residence time, capture and retention of allochthonous and autochthonous sediments and nutrients, both between and during flood pulses, is more efficient (Wetzel 2001, Olde Venterink et al. 2006). Because wetland biota have access to a larger pool of available nutrients, biomass may proliferate toward a maximum density and shift toward more eutrophic communities (Wetzel 2001). The consequent accumulation of organic detritus can be excessive, particularly where the influx of phosphorus and other agrichemical nutrients further exacerbates or accelerates eutrophication (Craft and Richardson 1993a, b). The rapid buildup of organic matter (in some cases 1-2 m) on top of sediments already occluding seed and invertebrate egg banks (Gleason et al. 2003) further compromise the reestablishment of original wetland communities.

The flushing of mineralized nutrients from impounded wetlands after sustained dry periods can keep eutrophication in check by exporting 
nutrients to downstream ecosystems (Turner and Haygarth 2001, Olde Venterink et al. 2002, Aldous et al. 2005, Mitsch and Gosselink 2007). However, sustained dry periods tend to become less frequent and reliable in impounded wetlands because control structures are not typically designed to simulate the dry marsh phase, and the excessive accumulations of detritus and root mats are difficult to dewater. The wetter moisture regime generally favors anoxia and consequently inhibits the release of nutrients that otherwise could contribute to pulses in primary production by slowing their mineralization in relation to aerobic processes (Brix 1993, Wetzel 2001, Mitsch and Gosselink 2007). Further, the flood peaks necessary to scour sediment and transport mineralized nutrient from the wetland are increasingly damped by impoundment, and accumulations of dense organic matter constrain direct contact between flowing waters and buried allochthonous sediment (Mitsch and Gosselink 2007). Thus, over time, it may become increasingly difficult for wetland managers to achieve the wet-dry sequences necessary for dynamic anaerobic-aerobic nutrient cycling sequences (Junk et al. 1989, Euliss et al. 2004) and the flushing of nutrients from the wetland.

Water-control structures may also profoundly affect the salinity and toxic chemical (natural and anthropogenic) burden in wetlands due to increased hydroperiods that favor evapotranspirative losses from the wetland and promote the evapoconcentration of solutes. The effects on the nature and health of biotic communities are likely to be most pronounced in drier or more arid regions where, due to a moisture deficit, salts or toxic substances (e.g., selenium) have the potential to accumulate at excessive levels harmful to biota (Seiler et al. 1999, Euliss and Mushet 2004, Nelson and Reiten 2006).

Thus, many problems that exist in managed wetlands result when alteration of natural hydrologic cycles subsequently alters ecosystem processes, setting up a poor ecological fit. Traditional management goals often strive to provide the same conditions from year to year without providing the temporal variability needed to emulate ecosystem processes. This may lead to decreasing productivity for target fish and wildlife because natural wetland hydrology has been stabilized (Euliss et al. 2004). Wetlands are "productive" because they dry out periodically, and wildlife populations, therefore, naturally fluctuate with hydrologic cycles in wetlands. Management for natural dynamic hydrologic processes is the key to maximizing diverse wetland services over long periods of time and avoiding costly remedial actions that may be required to return the wetland to a productive state. Managers, therefore, cannot consistently maintain large populations of specific groups of fish and wildlife through time without embracing variability in the system. Hydrology within the constraints of geomorphic features is paramount to restoring ecosystem processes at specific locations. Hydrologic variability is a form of natural disturbance that, when provided within proper constraints, can lead to increased diversity of plant communities and habitat for wildlife (e.g., Wilcox and Meeker 1991, 1992). Management actions that alter seasonality, depth, and duration of flooding or alter natural drawdown phases in wetlands may serve to meet short-term goals, but they have the long-term effect of reducing wetland diversity and productivity.

\section{WETLAND ECOLOGY AND MANAGEMENT: A NEW PERSPECTIVE}

We believe that the solution to move our field forward and provide effective wetland management in today's modified landscape will require a paradigm shift by wetland managers, applied scientists, natural resource agency administrators, and educators. However, we believe that the shift will be palatable and easy to implement because it will facilitate recognition and placement of management goals for conservation outcomes into basic wetland cycles (e.g., Harris and Marshall 1963, van der Valk and Davis 1978, Fredrickson and Taylor 1982, Smith 1990, Euliss et al. 2004).

The shift would stimulate a more ecosystem-based perspective that takes into account spatial and temporal processes required for long-term sustainable productivity. A major focus would be on restoring ecosystem processes. Infrastructures (e.g., water-control structures), if needed, would be scheduled to emulate critical processes that maximize the flow of energy between and among the trophic strata within managed wetlands. Emphasis would be placed on restoring the dynamic extremes of wetland cycles to provide habitat for the broad suite of wetland biota, both spatially and temporally.

With this management approach, the importance of a specific wetland to individual plant and animal communities will vary greatly from year-to-year such that the physical appearance and productivity would change on an inter-annual basis. The expression of temporal intra- and inter-annual variability provides great benefit because optimal conditions would be provided at all times, albeit for different species of plants and animals over time. 
Restoring processes within a temporal framework removes subjective values given to certain groups of wildlife and affords managers an objective base to develop and justify management actions. Hence, the focus would be on ecosystem function with the goal of intergenerational sustainability. Managers would, for example, focus on replication of critical ecosystem processes rather than simply setting pool depths based on the requirements of targeted species. Even species that do best when wetlands contain water, like waterfowl and amphibians, benefit from the dry phase that is needed to recycle nutrients required to enhance the food webs that they depend upon when wetlands reflood (e.g., Smith et al. 1964, Swanson et al. 2002, Euliss and Mushet 2004). Historically, wetland ecosystems fluctuated between wet and dry conditions, and the habitat they provided in any given year was good for some species and bad for others. However, the process generally optimized sustainability of the wetland ecosystem and optimized its value to a diverse plant and animal community.

Presently, our knowledge of basic ecosystem processes in wetlands is limited and fragmented among disciplines not traditionally included in fisheries and wildlife curricula. We have an even poorer understanding of how land-use change has altered basic ecosystem processes and how landscape-scale process alterations influence down-gradient managed wetlands. Organizing available information will identify data gaps for applied scientific investigations and provide a framework for process-based conservation management. Education will play a critical role in the transitioning from traditional to ecosystem process-based wetland management (Wilcox 2008).

\section{A NEW DIRECTION}

The knowledge needed to manage wetlands in today's modern landscape is broad, and much of the available information is scattered among various scientific disciplines, where it has generally been unavailable to wetland managers. There is a need to consolidate available and pertinent information to help develop the framework to facilitate management based on ecosystem processes. Scientific guidance is needed to support identified management actions in wetlands, including evaluation of the potential for success, development of methods that are compatible with the natural functions and processes of the wetlands, evaluation of success in specific applications, and follow-up studies to support adaptive management such that successful results can be retained. Research is also needed to evaluate prob- able long-term evolution of natural wetland ecosystems to allow development of trajectories and models for predicting how the managed ecosystems will behave into the future. Finally, there will be significant socio-political hurdles to surpass before we overcome the traditional paradigms within our discipline. Education will clearly play a role, and the broadened skill set required to be effective will enable our managers and scientists to communicate more effectively among ourselves and with the general public. Development of integrated management plans that seek to restore or maintain critical ecosystem processes within specific watersheds is an example where the knowledge required for the approach we suggest could be used to communicate the importance of critical ecosystem processes to diverse stakeholders and optimize wetland sustainability.

One approach for this research is to enhance understanding of the development, structure, and dynamics of the wetland ecosystems that are to be managed before considering management actions. Biological communities and processes can then be overlayed on the physical science structure, interactions between physical and biological processes can be assessed, wetland functions can be evaluated, and the effects of natural stressors on wetland ecosystems studied. With this background information, the role of human stressors and disturbances can be evaluated and quantified, including the influence of the increasingly urban and agricultural matrix in which natural areas are embedded. Management, restoration, and mitigation methodologies can then be developed for presentation to resource managers and policy-makers as appropriate.

The concept behind this approach is that wetlands occur at positions in the landscape where the underlying geology creates hydrologic conditions suitable for their development. Therefore, geology, landscape setting, hydrology, and developmental processes must be understood before interpretations of natural wetland functions and effects of management actions can be made. Wise management decisions are dependent on a thorough knowledge of how a wetland works. Management actions that defy natural processes will be doomed to an eternal battle with nature and will risk long-term, high maintenance costs or failure.

A step-wise mechanism is needed for using this approach. The landscape setting, underlying geology, resultant hydrology, ensuing biological development, time scale of development, and interactions should first be determined for the wetlands to be managed. Ideally, models of wetland ecosystems that demonstrate natural processes could be developed to provide managers with knowledge of the 
resources they manage, and reference sites could be established to document unmanaged wetland evolution. Chemical and physical properties of wetlands across the continuum from upland to aquatic environments and their role in determining distribution of biological systems should be characterized. Natural stressors, including stressor feedbacks among biological, chemical, and physical properties, should be identified. Spatial models of wetland ecosystems that incorporate landscape heterogeneity, fragmentation, connectivity, and barriers to biological movement between, within, and among components could be developed.

Scientific understanding of the effects of human stressors on the wetlands to be managed (i.e., disturbances that alter predisposed, natural processes outlined above) is required to evaluate influences from factors such as climate change, disruption of upland-to-aquatic linkages, shoreline modification, altered sediment supply and transport, altered hydrology, land-use change, development on uplands, chemical and microbiological alterations, invasive species, introduction of nonnative organisms, and disruption of fire regimes. The temporal implications of disturbance regimes can then be evaluated, including length of disturbance events, frequency of recurrence, severity, and long-term effects (e.g., Brinson 1993). It would then be possible to develop methods to quantify the effects of disturbance, including interaction of multiple threats and develop predictive tools and indicators for evaluating disturbance effects. Mechanistic models for wetland processes and disturbance effects could be developed that enable managers to understand the implications of disturbance regimes to habitats, biota, and critical processes that extend beyond the wetland being managed (Brinson 1993, Euliss and Laubhan 2005, Wilcox and Xie 2007).

Intuitively, several steps can be followed to increase scientific understanding of management, restoration, and mitigation methodologies. The realistic possibilities for reversing physical and biological changes or restoring degraded ecosystems first must be evaluated, thus allowing sound goals to be set (Smith et al. 2008). New and improved methods might be developed for managing, restoring, rehabilitating, protecting, and creating wetland ecosystems and their component flora and fauna that incorporate an ecosystem approach and establish or retain connectivity across the landscape. Models for predicting success of projects could also be developed, including indicators and performance criteria that quantify ecological responses (Euliss and Laubhan 2005, Wilcox and Xie 2007).
Finally, wetland scientists, working in partnership with managers, need to evaluate the success of applications of management practices to ensure relevance, including development of monitoring programs tailored to allow adaptive management that retains successes achieved. Scientific understanding of the potential future of the managed wetlands might be gained by evaluating the probable long-term evolution of the wetlands in the absence of human disturbance to understand how the natural system might have behaved if not disturbed or managed. Landscape and successional trajectories and models could then be developed that predict and project how the altered, managed wetlands will behave in the future.

A fundamental change required to meet the challenge for new information will be the broadening of our educational system, both at the undergraduate, graduate, and post-graduate level, to ensure that future resource managers are supplied with the broad background needed to meet future challenges. If agencies require this training of potential job applicants, it will facilitate change in education as well as resource management.

Research provides the hope for the new information needed to meet the changing needs of natural resource managers as land-use change further modifies the landscape and makes fish and wildlife management more difficult. However, research results are mostly disseminated in scientific meetings and journal articles that are outside the activities of many wetland managers. Therefore, alternative means of providing research results to managers are needed. The options include 1) developing agencysponsored workshops for managers in which wetland scientists make distilled and focused presentations on application of research to specific management problems; 2) crafting management-related symposia and workshops at professional scientific meetings that will draw managers into attendance; and 3) providing publications that focus directly on application of science to wetland management concerns.

Leopold (1949:173) defined conservation as the state of harmony between men and land. While Leopold's definition of conservation still applies, maintaining harmony between ourselves and the land has never been more challenging. Land-use change within the past 75 to 100 years has altered critical ecosystem processes at large scales, and our traditional perspective on wetland management needs to be expanded to be effective in the modern landscape. Hence, an understanding of basic ecosystem processes and how they affect specific wildlife conservation outcomes is requisite to manage today's environment for a sustainable future. Leo- 
pold also once stated, "An understanding of ecology does not necessarily originate in courses bearing ecological labels; it is quite likely to be labeled geography, botany, agronomy, history, or economics. This is as it should be, but whatever the label, ecological training is scarce" (Leopold 1949). The time to implement a plan that requires a more diverse curriculum be taught to wetland managers that will allow wetland ecosystems to be managed through broader ecosystem perspectives is long overdue.

\section{ACKNOWLEDGMENTS}

We thank D. P. Batzer, J. M. Bowling, M. M. Brinson, A. G. van der Valk, L. H. Fredrickson, M. K. Laubhan, and J. Gammonley for comments on a previous version of this manuscript. This manuscript is contribution number 1477 of the Great Lakes Science Center.

\section{LITERATURE CITED}

Aldous, A., P. McCormick, C. Ferguson, S. Graham, and C. Craft. 2005. Hydrologic regime controls soil phosphorus fluxes in restoration and undisturbed wetlands. Restoration Ecology $13: 341-47$

Baettie, M. 1996. An ecosystem approach to fish and wildlife conservation. Ecological Applications 6:696-99.

Bedford, B. L., M. R. Walbridge, and A. Aldous. 1999. Patterns in nutrient availability and plant diversity of temperate North American wetlands. Ecology 80:2151-69.

Bridgham, S. D., J. P. Megonigal, J. K. Keller, N. B. Bliss, and C. Trettin. 2006. The carbon balance of North American wetlands. Wetlands 4:889-916.

Brinson, M. M. 1993. A hydrogeomorphic classification for wetlands. U. S. Army Corps of Engineers Waterways Experiment Station, Vicksburg, MS, USA.Wetlands Research Program Technical Report WRP-DE-4.

Brix, H. 1993. Wastewater treatment in constructed wetlands: System design, removal processes, and treatment performance. p. 9-22. In G. A. Moshiri (ed.) Constructed Wetlands for Water Quality Improvement. Lewis Publishers, Boca Raton, FL, USA.

Christensen, N. L., A. M. Bartuska, J. H. Brown, S. Carpenter, C. D'Antonio, R. Francis, J. F. Franklin, J. A. MacMahon, R. F. Noss, D. J. Parsons, C. H. Peterson, M. G. Turner, and R. G. Woodmansee. 1996. The report of the Ecological Society of America Committee on the scientific basis for ecosystem management. Ecological Applications 6:665-91.

Craft, C. B. and C. J. Richardson. 1993a. Peat accretion and phosphorus accumulation along a eutrophication gradient in the northern Everglades. Biogeochemistry 22:133-56.

Craft, C. B. and C. J. Richardson. 1993b. Peat accretion and N, $\mathrm{P}$, and organic $\mathrm{C}$ accumulation in nutrient-enriched and unenriched Everglades peatlands. Ecological Applications 3:446-58.

Euliss, N. H. Jr., R. A. Gleason, A. Olness, R. L. McDougal, H. R. Murkin, R. D. Robarts, R. A. Bourbonniere, and B. G. Warner. 2006. North American prairie wetlands are important nonforested land-based carbon storage sites. Science of the Total Environment 361:179-88.

Euliss, N. H. Jr., J. W. LaBaugh, L. H. Fredrickson, D. M. Mushet, M. K. Laubhan, G. A. Swanson, T. C. Winter, D. O. Rosenberry, and R. D. Nelson. 2004. The wetland continuum: a conceptual framework for interpreting biological studies. Wetlands 24:448-58.
Euliss, N. H. Jr. and M. K. Laubhan. 2005. Quantifying the environmental benefits of the Conservation Reserve Program on prairie wetlands: separating acts of nature from acts of Congress. Proceedings of CRP: Planting for the Future. Ft. Collins, CO, USA.

Euliss, N. H. Jr. and D. M. Mushet. 2004. Impacts of water development on aquatic macroinvertebrates, amphibians, and plants in wetlands of a semi-arid landscape. Aquatic Ecosystem Health and Management 7:73-84.

Fredrickson, L. H. and T. S. Taylor. 1982. Management of seasonally flooded impoundments for wildlife. U. S. Fish and Wildlife Service Resource Publication 148.

GAO. 1994. Ecosystem management: additional actions needed to adequately test a promising approach. United States Government Accounting Office RCED-94-111.

Gleason, R. A., N. H. Euliss, Jr., D. E. Hubbard, and W. G. Duffy. 2003. Effects of sediment load on emergence of aquatic invertebrates and plants from wetland soil egg and seed banks. Wetlands 23:26-34.

Gosselink, J. G. and R. E. Turner. 1978. The role of hydrology in freshwater wetland ecosystems. p. 63-78. In R. E. Good, D. F. Whigham, and R. L. Simpson (eds.) Freshwater Wetlands. Academic Press, Inc., New York, NY, USA.

Harris, S. W. and W. H. Marshall. 1963. Ecology of water-level manipulations on a northern marsh. Ecology 44:331-43.

Heinz Report. 2002. The state of the nation's ecosystems: measuring the lands, waters, and living resources of the United States. H. John Heinz III (ed.) Center for Science, Economics, and the Environment, Cambridge University Press, Cambridge, UK.

Jaworski, E. and C. N. Raphael. 1978. Historical changes in natural diversity of fresh water wetlands, glaciated region of northern United States. p. 545-56. In P. E. Greeson, J. R. Clark, and J. E. Clark (eds.) Wetland Functions and Values: The State of Our Understanding. American Water Resources Association, Minneapolis, MN, USA.

Junk, W. J., P. B. Bayley, and R. E. Sparks. 1989. The flood-pulse concept in river floodplain systems. p. 110-27. In D. P. Dodge (ed.) Proceedings of the International Large River Symposium, Canadian Special Publication of Fisheries and Aquatic Sciences 106.

Kadlec, J. A. 1962. The effects of a drawdown on a waterfowl impoundment. Ecology 43:267-81.

Karlin, E. F. 1995. Population growth and the global environment: an ecological perspective. p. 19-37. In W. J. Makofske and E. F. Karlin (eds.) Technology, Development and Global Environmental Issues. Harper Collins College Publishers, New York, NY, USA.

Keough, J. R., T. A. Thompson, G. R. Guntenspergen, and D. A. Wilcox. 1999. Hydrogeomorphic factors and ecosystem response in coastal wetlands of the Great Lakes. Wetlands 19:821-34.

Leopold, A. 1949. A Sand County Almanac: With Essays on Conservation. Oxford University Press, New York, NY, USA.

Luo, H. R., L. M. Smith, B. L. Allen, and D. A. Haukos. 1997. Effects of sedimentation on playa wetland volume. Ecological Applications 7:247-52.

Mälson, K., I. Backéus, and H. Rydin. 2008. Long-term effects of drainage and initial effects of hydrological restoration on rich fen vegetation. Applied Vegetation Science 11:99-106.

Mensik, J. G. and F. L. Paveglio. 2004. Biological integrity, diversity, and environmental health policy and the attainment of refuge purposes: a Sacramento National Wildlife Refuge case study. Natural Resources Journal 44:1162-83.

Merbach, W., T. Kalettka, C. Rudat, and J. Augustin. 2002. Trace gas emissions from riparian areas of small eutrophic inland waters in Northeast Germany. p. 235-44. In G. Broll, W. Merbach, and E.-M. Pfeiffer (eds.) Wetlands in Central Europe-Soil Organisms, Soil Ecological Processes and Trace Gas Emissions. Springer-Verlag, Berlin, Germany.

Middleton, B. A. (ed.). 2002. Flood Pulsing in Wetlands: Restoring the Natural Hydrologic Balance. John Wiley \& Sons, Inc., New York, NY, USA. 
Mitsch, W. J. and J. G. Gosselink. 2007. Wetlands, fourth edition. John Wiley \& Sons, Inc., New York, NY, USA.

National Research Council. 1995. Wetlands-Characteristics and Boundaries. National Academy Press, Washington, DC, USA.

National Research Council. 2002. Riparian Areas: Functions and Strategies for Management. National Academy Press, Washington, DC, USA.

Nelson, K. A. and J. C. Reiten. 2006. Saline seep impacts on Hailstone and Halfbreed National Wildlife Refuges. U.S. Fish and Wildlife Service, Region 6 Contaminants Program, Denver, CO, USA. DEC ID: 2001600001, FFS: 61130-6N47.

Ohlendorf, H. M., D. J. Hoffman, M. K. Saiki, and T. W. Aldrich. 1986. Embryonic mortality and abnormalities of aquatic birds: apparent impacts by selenium from irrigation drainwater. Science of the Total Environment 52:49-63.

Olde Venterink, H., T. E. Davidsson, K. Kiehl, and L. Leonardson. 2002. Impact of drying and re-wetting on $\mathrm{N}, \mathrm{P}$ and $\mathrm{K}$ dynamics in a wetland soil. Plant and Soil 243:119-30.

Olde Venterink, H., J. E. Vermaat, M. Pronk, F. Weigman, G. E. M. van der Lee, M. W. van der Hoorn, L. W. G. Higler, and J. T. A. Verhoeven. 2006. Importance of sediment deposition and denitrification for nutrient retention in floodplain wetlands. Applied Vegetation Science 9:163-74

Reichman, O. J. and H. R. Pulliam. 1996. The scientific basis for ecosystem management. Ecological Applications 6:694-96.

Salyer, J. C. II and F. G. Gillet. 1964. Federal Refuges. p. 497-508. In J. P. Linduska (ed.) Waterfowl Tomorrow. U.S. Government Printing Office, Washington, DC, USA.

Seiler, R. L., J. P. Skorupa, and L. A. Peltz. 1999. Areas susceptible to irrigation-induced selenium contamination of water and biota in the western United States. U. S. Geological Survey Circular 1180

Skorupa, J. P. and H. M. Ohlendorf. 1991. Contaminants in drainage water and avian risk thresholds. p. 345-68. In A Dinar and D. Zilberman (eds.) The Economics and Management of Water and Drainage in Agriculture. Kluwer Academic Publishers, Norwell, MA, USA

Smith, A. G., J. H. Stoudt, and J. B. Gallop. 1964. Prairie potholes and marshes. p. 39-50. In J. P. Linduska (ed.) Waterfowl Tomorrow. U. S. Government Printing Office, Washington, DC, USA.

Smith, L. M. 1990. Waterfowl habitat management and research in North America. International Union of Game Biologists 19:468-76.

Smith, L. M., N. H. Euliss, Jr., D. A. Wilcox, and M. M. Brinson. 2008. Wetland management case histories; consequences of a static view and application of the geomorphic/time variable paradigm. Wetlands 28:563-77.
Swanson, G. A. 1992. Cycles of cattails in individual wetlands: environmental influences. p. 13-17. In Proceedings of the Cattail Management Symposium. North Dakota State University, Fargo, ND, USA.

Swanson, G. A., N. H. Euliss, Jr., B. A. Hanson, and D. M. Mushet. 2003. Dynamics of a prairie pothole wetland complex: implications for wetland management. p. 55-94. In T. C. Winter (ed.) Hydrological, chemical, and biological characteristics of a prairie pothole wetland complex under highly variable climate conditions - the Cottonwood Lake Area, east-central North Dakota. U.S. Geological Survey Professional Paper 1675.

Turner, B. L. and P. M. Haygarth. 2001. Phosphorus solubilization in rewetted soils. Nature 411:258.

U.S. Environmental Protection Agency. 2000. National water quality inventory: 2000 report to Congress. U.S. Environmental Protection Agency, Washington, DC, USA. EPA841-R-02-001.

van der Valk, A. G. and C. B. Davis. 1978. The role of seed banks in the vegetation dynamics of prairie glacial marshes. Ecology 59:322-35.

Weller, M. W. and L. H. Fredrickson. 1974. Avian ecology of a managed glacial marsh. The Living Bird 12:269-81.

Weller, M. W. and C. S. Spatcher. 1965. Role of habitat in the distribution and abundance of marsh birds. Iowa Agriculture and Home Economics Experimental Station, Ames, IA, USA. Special Report 43.

Wetzel, R. G. 2001. Limnology. Academic Press, San Diego, CA, USA.

Wilcox, D. A. 2008. Education and training of future wetland scientists and managers. Wetlands 28:578-84.

Wilcox, D. A. and J. E. Meeker. 1991. Disturbance effects on aquatic vegetation in regulated and non-regulated lakes in northern Minnesota. Canadian Journal of Botany 69: $1542-51$.

Wilcox, D. A. and J. E. Meeker. 1992. Implications for faunal habitat related to altered macrophyte structure in regulated lakes in northern Minnesota. Wetlands 12:192-203.

Wilcox, D. A. and Y. Xie. 2007. Predicting wetland plant response to proposed water-level-regulation plans for Lake Ontario: GIS-based modeling. Journal of Great Lakes Research 33:751-73.

Winter, T. C. 2003. Geohydrologic setting of the Cottonwood Lake Area. p. 1-24. In T. C. Winter (ed.) Hydrological, chemical, and biological characteristics of a prairie pothole wetland complex under highly variable climate conditions - the Cottonwood Lake Area, east-central North Dakota. U.S. Geological Survey, Professional Paper 1675.

Manuscript received 20 August 2007; accepted 4 March 2008. 